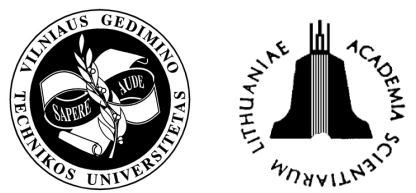

ISSN 1648-4142 print / ISSN 1648-3480 online TRANSPORT

www.transport.vgtu.lt

\title{
MODEL FOR PROBABILISTIC ASSESSMENT OF OIL OUTFLOW EVENT CAUSED BY TANKER ACCIDENT
}

\author{
Mindaugas Česnauskis \\ Lithuanian Maritime Safety Administration, J. Janonio g. 24, LT-92251 Klaipeda, Lithuania \\ Tel.: +370 46 469640, Fax: +370 46469600, E-mail: info@msa.lt
}

Received 26 January 2007; accepted 2 May 2007

\begin{abstract}
Model proposed in this paper can be used to predict oil outflow event, caused by the tanker accident, probability distribution in different sectors of navigation area. The use of expert judgment techniques to obtain necessary data for application of the model ensures that all relevant available information (world and regional marine accident statistics, factors inherent to navigational area in question) will be duly taken into account. Model is designed for the Lithuanian responsibility sea area; the assessment of probability of oil outflow event and its distribution in different sectors of the area is performed.
\end{abstract}

Keywords: tanker accident, probability of oil outflow event, Lithuanian responsibility sea area.

\section{Introduction}

Among other sources of pollution at sea, oil outflow from tankers during the accident poses the biggest threat to the marine environment [1]. The consequences caused by this source of pollution depend not only on factors dominating in the area where an accident takes place, but also on expeditious deployment of appropriate combating means. Having available the probability distribution in different segments of sea area and estimated quantity of oil spilt during the tanker accident [2], calculation of risk posed by tankers for each of the segments of the sea area can be performed. The level of such risk is mostly needed in two cases:

- when dislocation and development of operative marine pollution combating means in navigation area is exercised;

- when hazard reduction measures in high risk sea areas are applied.

Methods currently used for estimation of probability of oil outflow event caused by tanker accident are not sufficiently effective, in certain cases they do not account for all crucial factors influencing this probability. Therefore results obtained by using such methods are not always reliable.

The objective of this research was to analyse methods currently used for estimation of oil outflow event probability and to prepare revised methodology, suitable for prognosis of oil outflow event probability distribution in different zones of the Lithuanian responsibility sea area (or other similar areas in terms of length of coastline, size, tanker traffic density, number of oil terminals), as well as for preliminary estimation of the absolute value of such probability.

The methodology does not address deliberate and accidental oil spills, as well oil spills which may take place during tanker loading and unloading operations in the terminal, or during terrorist attacks. Methods, used for evaluation of such sources of pollution differ in principle from those which are analysed in this paper.

The method proposed in this paper is based on the modelling of pollution process from tanker by using event tree analysis and by distributing pollution event probability to different zones of sea area and to possible tanker accident categories.

As additional source of data, the proposed methodology in certain cases may supplement the emergency situations in terminal probability model [3], and the theory of assessment of statistical probability of the technological transportation process [4].

\section{Methods used for estimation of pollution event probability}

In order to calculate probability of pollution, caused by tanker accident, two parameters are needed: tanker accident rate in the navigation area and probability of pollution event, when tanker accident takes place.

Prognosis of probability of tanker collision and stranding/grounding mainly is based on ships accident statistics [5-7]. This method, combined with assessed peculiarities of tanker navigation route was used by V. Smailys et al. for evaluation of tanker accident probability in the Lithuanian responsibility sea area $[8,9]$. 
Other researchers $[10,11]$ are in favour of application of expert judgment techniques. This method is one of the tools, recommended in the formal safety assessment (FSA) methodology [12], which is designated for evaluation of new regulations for maritime safety, and approved by the International Maritime Organisation (IMO).

Sabine Knapp and Philip Hans Franses investigated the relation between the non-compliance of a ship with the maritime safety standards and ships accident rate [13]. The performed research with more than 50000 ships has revealed that there exists a correlation between these two variables.

V. Paulauskas analysed factors, influencing ship's navigational risk, and proposed methodology for navigational risk assessment of ships in big navigational areas such as the Baltic Sea [14]. In the research the author points out, that for individual navigational areas in the Baltic Sea additional risk investigation is necessary. The research does not address the prognosis of probability of oil outflow event, when tanker accident takes place.

The ship accident statistics is used for prognosis of fires/explosions and structural failures [7]. Investigations show, that probability of structural failure depends not only on technical condition of the hull of the ship, but also on average wave height in the area where the ship is operating [15]. It is worth to note, that in this respect the Baltic Sea belongs to the lower risk area.

The probability of oil outflow event, triggered by collision or stranding/grounding, mostly depends on the construction of the hull of the tanker. In terms of reliability for the prognosis of such probability most suitable is IMO approved probabilistic methodology [16]. According to it, numbers of calculations with tankers were conducted by different researchers [17].

There are no specific methodologies for evaluation of oil outflow event probability in case of fire or structural failure. Therefore the best way of evaluation of such events is to rely on the statistics [11].

All methods described above are designed either for evaluation of pollution risk of particular tanker (in that case peculiarities of the region where tankers are operating remain disregarded), or on the contrary, concentrate on peculiarities of particular region (in that case tanker factors remain untouched). Therefore these methods, when applied separately, do not allow conducting thorough and reliable prognosis of distribution of probability of oil outflow event in different sectors of navigation area.

Approach, proposed in this article ensures, that final result is obtained by complex evaluation of ship accident statistics, particulars of tankers operating in navigational area, as well as other dominating factors which may increase the reliability of the research.

The model includes certain elements of FSA methodology [12] (hazard identification, modeling and ranking of scenarios), as well as principles of expert judgment [18] used in risk assessment.

\section{Modeling of oil outflow event from tanker process}

The probability of oil outflow event from tanker in different sectors of navigational area due to different environmental, navigational and other kind of factors, as well as due to existing traffic separation schemes in the area, may differ quite a big number of times. In order to estimate distribution of such probability in different places of navigational area, the latter shall be divided in $Z$ number of zones. In order to ensure high level of reliability of final result, the division of the area shall be performed in the manner that variation of the factors, dominating in each zone, and influencing tanker accident probability, would be as low as possible.

Estimation of oil outflow event probability distribution in each of the zones of navigational area will be based on the principle, that oil outflow event, triggered by tanker accident occurs as necessary event. Therefore the task is to distribute the numeric values of this full probability to each of the modelled zones, by tanker accident category (see Fig 1).

For any oil outflow event $T$, which may occur in zone $z$ of the navigational area, we can model finite number $M$ of scenarios $S_{z m}$. Let us assume, that any event $T$ is triggered by one of the possible tanker accident categories - stranding/grounding $\left(K_{z 1}\right)$, collision $\left(K_{z 2}\right)$, fire/explosion $\left(K_{z 3}\right)$, structural failure of the hull $\left(K_{z 4}\right)$, (see Fig 1$)$. Then the sum of probabilities of modelled tanker accident scenarios in particular zone $z$ can be grouped by the accident categories:

$$
P_{z}=\sum_{m=1}^{M} P\left(S_{z m}\right)=\sum_{k=1}^{4} P\left(K_{z k}\right),
$$

where $P_{z}$ - probability of oil outflow event in zone $z$; $P\left(S_{z m}\right)$ - probability of appearance of $m$ scenario in zone $z$; $P\left(K_{z k}\right)$ - probability of $k$ category accident with tanker.

We can model $M, N, \ldots, R$ numbers of scenarios for each of the zones of the navigational area. Sum of probabilities of scenarios, modelled for the whole navigational area will be equal to the sum of the probabilities of all oil outflow events, grouped by zone and by tanker accident category. Full probability of oil outflow event, triggered by tanker accident in the whole navigational area will be equal to:

$$
\begin{aligned}
& \sum_{m=1}^{M} P\left(S_{1 m}\right)+\sum_{n=1}^{N} P\left(S_{2 n}\right)+\ldots+\sum_{r=1}^{R} P\left(S_{Z r}\right)= \\
& \sum_{z=1}^{Z} \sum_{k=1}^{4} P\left(K_{z k}\right) .
\end{aligned}
$$

Then, probability of $k$ category tanker accident in zone $z$, followed by oil outflow $-P\left(K_{z k} \mid T\right)$, can be calculated according to English mathematician Bayesian theorem:

$$
P\left(K_{z k} \mid T\right)=\frac{P\left(K_{z k}\right) \cdot P\left(T \mid K_{z k}\right)}{\sum_{k=1}^{4} P\left(K_{z k}\right) \cdot P\left(T \mid K_{z k}\right)},
$$

where $P\left(T \mid K_{z k}\right)$ - probability of oil outflow, in zone $z$ which may occur due to $k$ category tanker accident. 
Zone of the accident $(z)$
Accident scenarios
Accident category*
Oil outflow event, caused by tanker accident

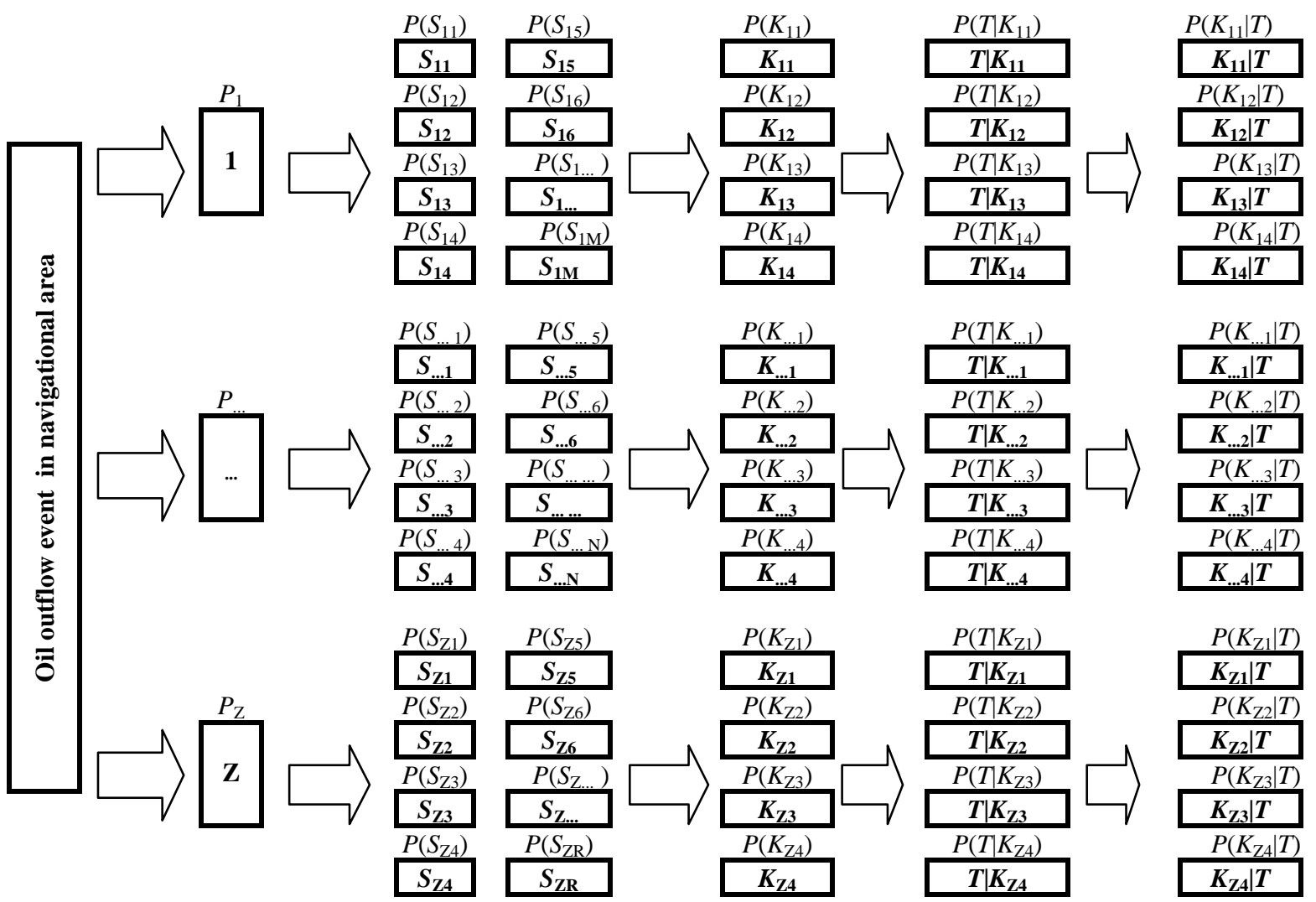

$* K_{1}-$ stranding/grounding; $K_{2}-$ collision; $K_{3}$ - fire/explosion; $K_{4}-$ structural failure of the hull

Fig 1. Oil outflow from tanker process diagram (event tree)

Sum of probabilities of oil outflow events $P\left(K_{z k} \mid T\right)$ in the whole navigational area will be equal to 1 and can be expressed by the following equation:

$$
\sum_{k=1}^{4} \sum_{Z=1}^{Z} \frac{P\left(K_{z k}\right) \cdot P\left(T \mid K_{z k}\right)}{\sum_{k=1}^{4} P\left(K_{z k}\right) \cdot P\left(T \mid K_{z k}\right)}=1 .
$$

This model can be applied for calculation of oil outflow event caused by tanker accident probability distribution by zones and accident categories.

Probability of oil outflow event in the navigational area per calendar year caused by accident of single tanker will be equal to:

$$
P_{T}=P_{t y} \frac{t_{\Sigma}-t_{k}}{365} k
$$

where $P_{t y}$ - average probability of accident of single operated tanker per year (loading and unloading time as well as repair time is not included); $t_{\Sigma}$ - average operational time of tanker in navigational area (days); $t_{k}$ average tanker transhipment time in the terminal (days); $k$ - probability, reflecting which part of tanker accidents triggers oil outflow.
According to Poisson distribution law, probability of at least single oil outflow event, caused by tanker accident, will be expressed as:

$$
P_{\Sigma T}=1-e^{-n P_{t y} \frac{t_{\Sigma}-t_{k}}{365} k},
$$

where $n$ - average number of tankers, entering the navigational area, per year.

Having statistical oil outflow from tanker probability in the whole navigational area, absolute value of probability of outflow event in zone $z$, triggered by one of the four possible categories $k$ of tanker accident $P_{A}\left(K_{z k} \mid T\right)$ will be equal to:

$$
\begin{aligned}
& P_{A}\left(K_{z k} \mid T\right)= \\
& {\left[1-e^{-n P_{t y} \frac{t_{\Sigma}-t_{k}}{365} k}\right] \frac{P\left(K_{z k}\right) \cdot P\left(T \mid K_{z k}\right)}{\sum_{K=1}^{4} P\left(K_{z k}\right) \cdot P\left(T \mid K_{z k}\right)} .}
\end{aligned}
$$

Equation can be used for calculation of absolute value of oil outflow event probability in each of the zones of navigational area (see Fig 1). However for practical application of the theory it is necessary to assess unknown parameters. 


\section{Assessment of parameters to be used for application of oil outflow probability evaluation model}

According to available research data [17], probability of oil outflow event in case of tanker stranding/grounding depends on the peculiarities (the prognosis of which is impossible) of the accident and on the hull construction - in particular on the distance between double bottom, and increases dramatically in case of single bottom tanker. The numeric value of aforementioned probability for double bottom tankers in average is equal to $P\left(T \mid K_{z 1}\right) \approx 0,1$. As far as all tankers, which are operating in the market have double bottom, this numeric value can be used for calculations.

The probability of oil outflow event in case of collision $P\left(T \mid K_{z 2}\right)$ correlates with the distance between double hulls, and depending on the construction of the particular tanker, varies between 0,15 and 0,2 . In case of single hull tanker this probability is equal $0,8 \ldots 0,9$. As single hull tankers form a significant part in the tanker market, probability $P\left(T \mid K_{z 2}\right)$ shall be based on juncture of tankers operating in particular zone of navigational area.

Oil outflow probabilities in case of fire/explosion and hull structural failure, according to investigation data on 789 tankers [19], can be assumed to be equal to $P\left(T \mid K_{z 3}\right)=0,06$ and $P\left(T \mid K_{z 4}\right)=0,14$ correspondingly.

Other parameters, necessary for the application of the model, depend on characteristics of navigational area. Having available only limited tanker accident statistics in the area, these parameters can not, to satisfied extent of reliability, be estimated by extrapolating past events to the future. Therefore in case of limited accident statistics in the area, estimation of certain parameters should be performed by using expert judgment methodologies. Table 1 contains the list of stages and parameters, necessary for calculations of oil outflow event probability, as well as methodologies and recommendations for estimation of parameters, relevant to appropriate stage.

In order to ensure reliable results, related to scenario modelling and ranking (stages 2 and 3, see Table 1), the reliability assessment should be performed (4 th stage). This should be conducted in the following order: $J$ number of experts should be tasked to rank a $I$ number of accident scenarios, using the natural numbers $1,2,3, \ldots, I$ (lesser number corresponds to higher accident risk). Therefore expert " $j$ " assigns rank $x_{i j}$ to scenario " $P$ ". The concordance coefficient $W[20,21]$ may be calculated by the following formula:

$$
W=\frac{12 \sum_{i=1}^{i=I}\left[\sum_{j=1}^{j=J} x_{i j}-\frac{1}{2} J(I+1)\right]^{2}}{J^{2}\left(I^{3}-I\right)} .
$$

The coefficient $W$ varies from 0 to 1 . $W=0$ indicates that there is no agreement between the experts as to how the scenarios are ranked. $W=1$ means that all experts rank scenarios equally. The level of agreement is characterized as follows: $W>0,7$ acceptable, good agreement; $W=$ $0,5 \ldots 0,7$ minimum acceptable; $W<0,5$ not acceptable.

\section{Results of application of probabilistic assessment model for Lithuanian responsibility sea area}

Probabilistic oil outflow assessment was conducted for Lithuanian responsibility sea area (hereinafter LRSA). Fig 2 contains scheme of LSRA division to separate zones. Zone 1 includes Klaipeda Port and its approaches (in this zone transhipment of cargo is executed, tanker possibly may stand on the road), 2 - Būtingè Oil Terminal transhipment area, 3 - ships traffic line to Klaipeda Port, 4 - tanker traffic line to and from Būtingè Oil Terminal, zone 5 corresponds to area, where exists probabil-

Table 1. Recommended parameter (to be used for oil outflow probability event calculations) assessment procedure

\begin{tabular}{|c|c|c|c|}
\hline \multicolumn{2}{|c|}{$\begin{array}{l}\text { Description of oil outflow } \\
\text { probability assessment stage }\end{array}$} & Method, recommended for assessment & Remarks \\
\hline 1 & $\begin{array}{l}\text { Establishment of proba- } \\
\text { bilities } P_{z} \text { for each zone } \\
\text { of navigational area }\end{array}$ & $\begin{array}{l}\text { Numeric values of probabilities should be established } \\
\text { by shipping experts. Experts should be familiar with } \\
\text { ship accident statistics in navigational area }\end{array}$ & $\begin{array}{l}\text { Experts should be selected following } \\
\text { established appropriate qualification re- } \\
\text { quirements. Evaluation should be per- } \\
\text { formed by at least two experts, by unani- } \\
\text { mous agreement. }\end{array}$ \\
\hline 2 & Scenario modelling & $\begin{array}{l}\text { Scenarios should be modeled taking due account of } \\
\text { the world and regional ships accident statistics, as well } \\
\text { as to peculiarities of each of the zone of navigational } \\
\text { area, and other factors influencing oil outflow process. }\end{array}$ & $\begin{array}{l}\text { One expert is sufficient to perform sce- } \\
\text { nario modelling process. }\end{array}$ \\
\hline 3 & Scenario ranking & $\begin{array}{l}\text { Scenario ranking should be performed by at least } 4 \\
\text { shipping experts. Each expert, taking into account } \\
\text { associated risks, performs scenario ranking. }\end{array}$ & $\begin{array}{l}\text { Each expert conducts scenario ranking } \\
\text { separately. }\end{array}$ \\
\hline 4 & $\begin{array}{l}\text { Reliability assessment } \\
\text { of performed scenario } \\
\text { modelling and scenario } \\
\text { ranking }\end{array}$ & $\begin{array}{l}\text { Reliability assessment should be performed accord- } \\
\text { ing to (8) equation. }\end{array}$ & $\begin{array}{l}\text { In case of satisfactory results of reliabil- } \\
\text { ity assessment, follow-up actions shall be } \\
\text { performed. Otherwise, revision of mod- } \\
\text { elled scenario definitions is necessary. }\end{array}$ \\
\hline 5 & $\begin{array}{l}\text { Estimation of tanker ac- } \\
\text { cident probability } P\left(K_{z k}\right) \\
\text { distribution by accident } \\
\text { category }\end{array}$ & $\begin{array}{l}\text { At least } 2 \text { shipping experts, following (1) equation, } \\
\text { shall set the probabilities of each modelled scenario } \\
S_{1 m}, S_{2 n}, \ldots, S_{z r} \text {. The probabilities shall be grouped in } 4 \\
\text { groups which correspond to tanker accident category. }\end{array}$ & $\begin{array}{l}\text { Experts should be selected following es- } \\
\text { tablished appropriate qualification re- } \\
\text { quirements. Experts should take deci- } \\
\text { sions by unanimous agreement. }\end{array}$ \\
\hline
\end{tabular}




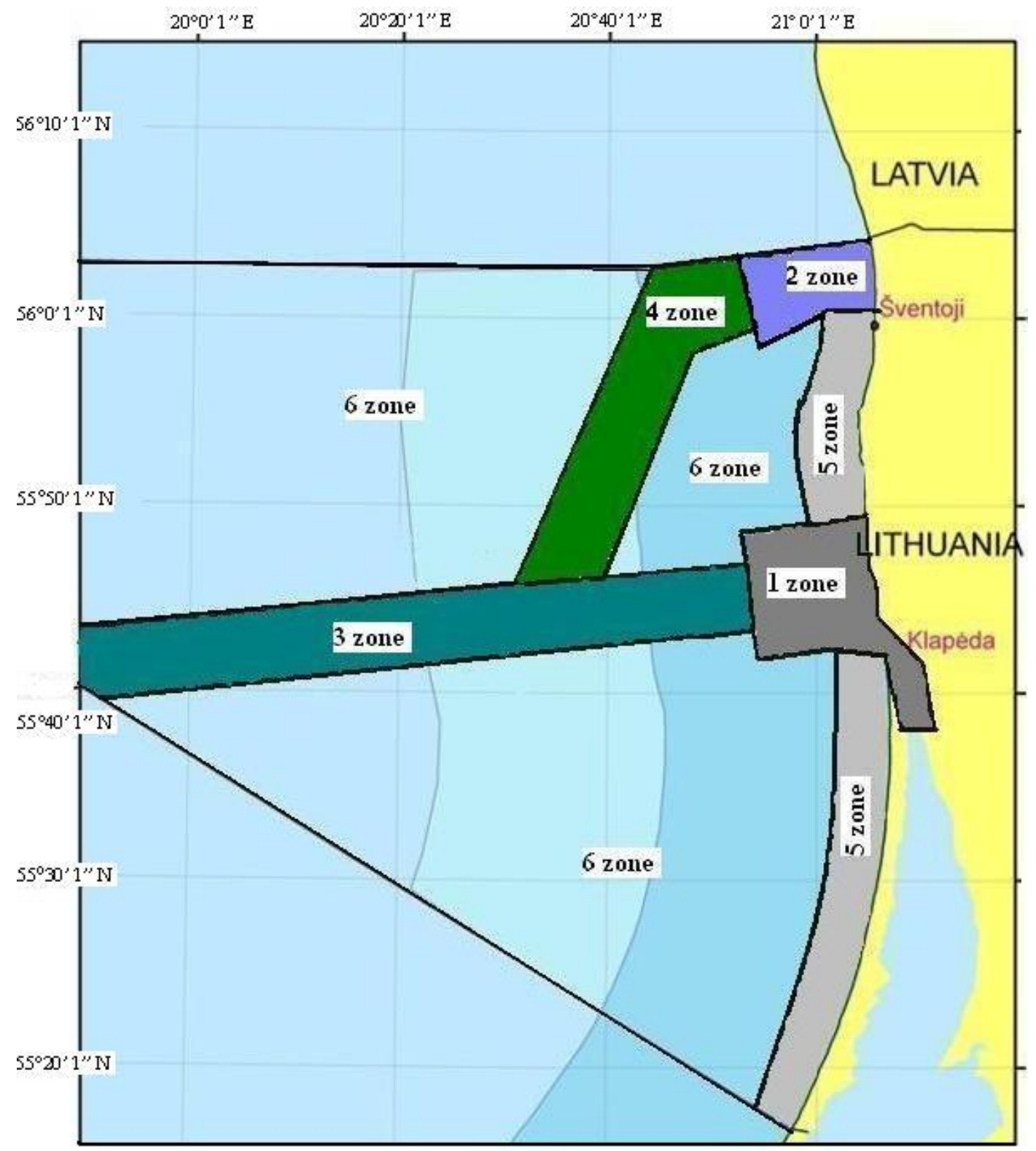

Fig 2. Division of LRSA by zones of different oil outflow probability

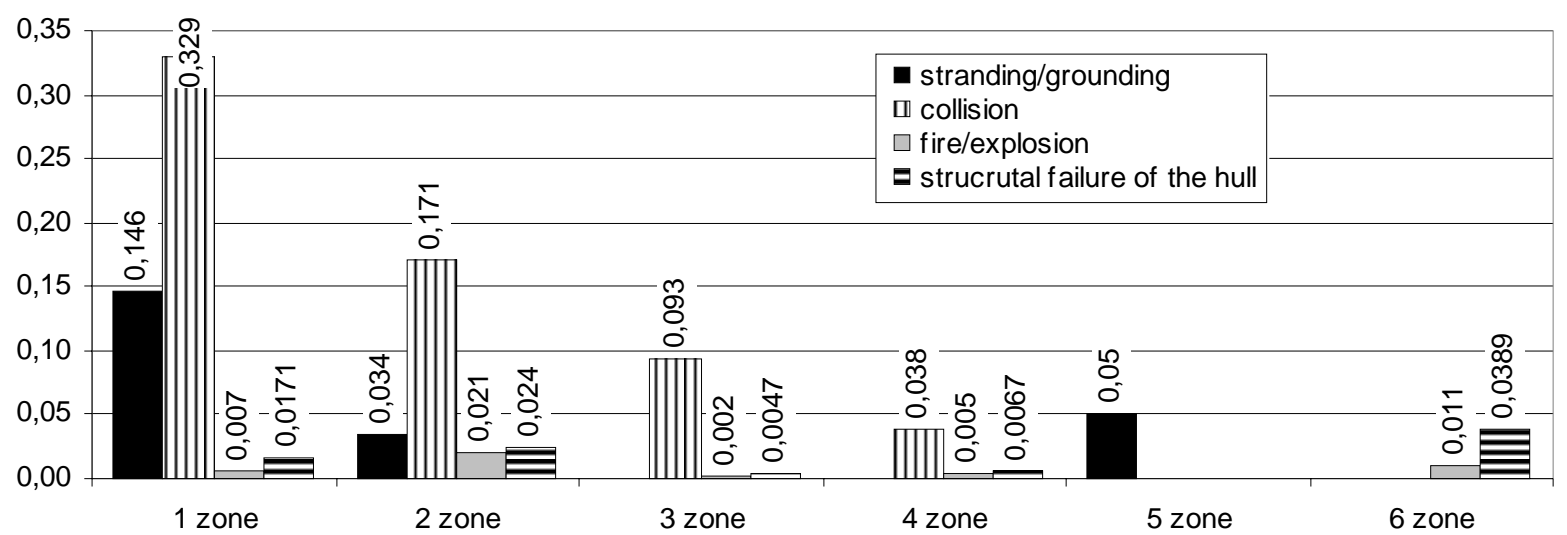

Fig 3. Oil outflow event full probability distribution by LRSA zones and by tanker accident category 
Table 2. Probabilistic parameters set for LRSA

\begin{tabular}{|c|c|c|c|c|}
\hline $\begin{array}{c}\text { LRSA } \\
\text { zone }\end{array} \mid$ & $P_{Z}$ & $\begin{array}{l}\text { Accident } \\
\text { category* }\end{array}$ & $\begin{array}{c}\text { Tanker accident } \\
\text { probability } \\
P\left(K_{z k}\right) \\
\end{array}$ & $\begin{array}{l}\text { Oil outflow pro- } \\
\text { bability in case of } \\
\text { accident } P\left(T \mid K_{z k}\right)\end{array}$ \\
\hline \multirow{4}{*}{$Z_{1}$} & \multirow{4}{*}{0,5} & $K_{1}$ & 0,3 & 0,1 \\
\hline & & $K_{2}$ & 0,15 & 0,45 \\
\hline & & $K_{3}$ & 0,025 & 0,06 \\
\hline & & $K_{4}$ & 0,025 & 0,14 \\
\hline \multirow{4}{*}{$Z_{2}$} & \multirow{4}{*}{0,25} & $K_{1}$ & 0,05 & 0,1 \\
\hline & & $K_{2}$ & 0,125 & 0,2 \\
\hline & & $K_{3}$ & 0,05 & 0,06 \\
\hline & & $K_{4}$ & 0,025 & 0,14 \\
\hline \multirow{4}{*}{$Z_{3}$} & \multirow{4}{*}{0,1} & $K_{1}$ & 0 & - \\
\hline & & $K_{2}$ & 0,08 & 0,35 \\
\hline & & $K_{3}$ & 0,01 & 0,06 \\
\hline & & $K_{4}$ & 0,01 & 0,14 \\
\hline \multirow{4}{*}{$Z_{4}$} & \multirow{4}{*}{0,05} & $K_{1}$ & 0 & - \\
\hline & & $K_{2}$ & 0,03 & 0,2 \\
\hline & & $K_{3}$ & 0,0125 & 0,06 \\
\hline & & $K_{4}$ & 0,0075 & 0,14 \\
\hline \multirow{4}{*}{$Z_{5}$} & \multirow{4}{*}{0,05} & $K_{1}$ & 0,05 & 0,1 \\
\hline & & $K_{2}$ & 0 & - \\
\hline & & $K_{3}$ & 0 & - \\
\hline & & $K_{4}$ & 0 & - \\
\hline \multirow{4}{*}{$Z_{6}$} & \multirow{4}{*}{0,05} & $K_{1}$ & 0 & - \\
\hline & & $K_{2}$ & 0 & - \\
\hline & & $K_{3}$ & 0,02 & 0,06 \\
\hline & & $K_{4}$ & 0,03 & 0,14 \\
\hline
\end{tabular}

Table 3. Results of scenario ranking, performed by experts

\begin{tabular}{|c|c|c|c|c|c|c|c|c|c|c|}
\hline \multirow{2}{*}{$\begin{array}{c}\text { LRSA } \\
\text { zone (see } \\
\text { Fig 2) }\end{array}$} & \multirow[t]{2}{*}{ Experts* } & \multicolumn{8}{|c|}{$\begin{array}{l}\text { Modelled scenarios } \\
\quad \text { (see Table 4) }\end{array}$} & \multirow[t]{2}{*}{$W$} \\
\hline & & $S_{z 1}$ & $S_{z 2}$ & $S_{z 3}$ & $S_{z 4}$ & $S_{z 5}$ & $S_{z 6}$ & $S_{z 7}$ & $S_{z 8}$ & \\
\hline \multirow{4}{*}{1} & $\mathrm{I}$ & 1 & 2 & 3 & 5 & 4 & 6 & 8 & 7 & \multirow{4}{*}{0,945} \\
\hline & II & 2 & 1 & 4 & 3 & 5 & 6 & 7 & 8 & \\
\hline & III & 1 & 2 & 4 & 3 & 5 & 6 & 7 & 8 & \\
\hline & IV & 2 & 1 & 3 & 4 & 5 & 6 & 7 & 8 & \\
\hline \multirow{4}{*}{2} & I & 5 & - & 2 & 4 & 1 & 3 & 7 & 6 & \multirow{4}{*}{0,903} \\
\hline & II & 4 & - & 1 & 5 & 2 & 3 & 7 & 6 & \\
\hline & III & 5 & - & 3 & 4 & 1 & 2 & 6 & 7 & \\
\hline & IV & 5 & - & 1 & 4 & 3 & 2 & 6 & 7 & \\
\hline \multirow{4}{*}{3} & $\mathrm{I}$ & - & - & - & 1 & - & - & 2 & 3 & \multirow{4}{*}{0,848} \\
\hline & II & - & - & - & 1 & - & - & 2 & 3 & \\
\hline & III & - & - & - & 1 & - & - & 2 & 3 & \\
\hline & IV & - & - & - & 1 & - & - & 3 & 2 & \\
\hline \multirow{4}{*}{4} & $\mathrm{I}$ & - & - & - & 1 & - & - & 2 & 3 & \multirow{4}{*}{0,848} \\
\hline & II & - & - & - & 1 & - & - & 2 & 3 & \\
\hline & III & - & - & - & 1 & - & - & 2 & 3 & \\
\hline & IV & - & - & - & 1 & - & - & 3 & 2 & \\
\hline \multicolumn{11}{|c|}{$\begin{array}{l}\text { * Expert judgment was performed by } 4 \text { shipping experts: } 2 \text { of them } \\
\text { have had } 7 \text {-year working experience at sea as navigators, the third } \\
\text { expert }-8 \text {-year working experience in conducting marine accident } \\
\text { investigation, and the last expert - } 12 \text {-year ships engineer experi- } \\
\text { ence serving on board the ship. }\end{array}$} \\
\hline
\end{tabular}

ity of tanker stranding/grounding in case of deviation from course. Zone 6 contains the remaining LRSA, with no tanker traffic. It is worth to note, that width of zones 3 and 4 is equal to 4 n.m., depths dominating in zone 5 compromise safe navigation in terms of stranding/grounding. Therefore, division of LRSA was performed according to the principle of even distribution of factors, influencing accident probability in particular zone.

Numeric values of oil outflow probability in case of tanker accident $P\left(T \mid K_{z k}\right.$ ) (Table 2) were selected after consideration of juncture of tanker hull construction (in 2003-2006 overwhelming majority of tankers, which entered Butingè Oil Terminal had double hull construction, and tankers, which entered Klaipèda Port, were divided equally in terms of single and double hull construction), as well as taking into account recommendations, provided in the previous chapter of this paper.

Other parameters $\left(P_{Z}\right.$ and $P\left(K_{z k}\right)$, see Table 2$)$, necessary for calculations of distribution oil outflow event probability by LRSA zones and by tanker accident categories, were evaluated by shipping experts (data on experts qualifications is presented in Table 3), following recommendations set forth in Table 1.

Table 4 contains tanker accident scenarios, which can lead to oil outflow event in particular LRSA zone. After scenario ranking, performed by 4 shipping experts (results are presented in Table 3), reliability assessment was conducted (stage 4 in Table 1).

Calculated concordance coefficients $W$ for LRSA zones 1-4 (Table 3) show, that level of agreement between experts is good (zones 5 and 6 due to extremely low oil outflow probability were not ranked). Oil outflow event full probability distribution by LRSA zones and by tanker accident category, calculated in accordance with (3) equation, is presented in Fig 3. Probability of occurrence of at least one oil outflow event in LRSA $P_{\Sigma T}$ was calculated using (6) formula.

It was assumed, that per calendar year $n=600$ tankers enter LRSA, each of them operating there $t_{\Sigma}=$ 1,7 days on average. Average tanker transhipment time in the terminal (Klaipeda Port and Būtingè Oil Terminal) is $t_{k}=0,8$ days. According to the accident statistics [7], for tanker, operated in the world market, average accident probability per year (repair and transshipment times excluded) is equal to $P_{t y}=0,065$. According to pollution by tankers statistics $[6,19]$, probability reflecting which part of tanker accidents triggers oil outflow is equal $k=0,12$. Therefore $P_{\Sigma_{T}}=0,01147$ (approximately once per 87 years). For comparison, according to results presented in relevant study conducted by Klaipeda University in 1997 [8], oil outflow event frequency in LRSA - 1 accident per 16-17 years. Such big differences resulted from different data used for estimations. The biggest impact was influenced by the fact that statistical frequency of tanker accidents declined sharply in the last decade. According to the data provided by Intertanko, in the time span between 1992 and 2004, tanker accident rate declined 5 times. Moreover, 
Table 4. Tanker accident scenarios modelled for LRSA and corresponding parameters

\begin{tabular}{|c|c|c|c|c|c|c|c|c|}
\hline \multirow[t]{2}{*}{$\begin{array}{l}\text { Accident } \\
\text { category }\end{array}$} & \multirow{2}{*}{\multicolumn{2}{|c|}{ Modelled scenarios }} & \multicolumn{6}{|c|}{$\begin{array}{l}\text { Oil outflow event } \\
\text { zone in LRSA (Fig } \\
\text { 2) }\end{array}$} \\
\hline & & & 1 & 2 & 3 & 4 & 5 & 6 \\
\hline \multirow{3}{*}{$K_{1}$} & $S_{z 1}$ & $\begin{array}{l}\text { Due to misconduct of crew or personnel ashore, tanker deviates from course, runs } \\
\text { aground and suffers bottom damage. }\end{array}$ & $\mathrm{x}$ & $\mathrm{x}$ & & & $\mathrm{x}$ & \\
\hline & $S_{z 2}$ & $\begin{array}{l}\text { Tanker, passing fairway, due to overloading or inaccuracies in navigational chart, touches } \\
\text { the ground and suffers bottom damage. }\end{array}$ & $\mathrm{x}$ & & & & & \\
\hline & $S_{z 3}$ & $\begin{array}{l}\text { Due to mechanical failure (steering or motion loss), tanker deviates from course, runs } \\
\text { aground and suffers bottom damage. }\end{array}$ & $\mathrm{x}$ & $\mathrm{x}$ & & & $\mathrm{x}$ & \\
\hline \multirow{3}{*}{$K_{2}$} & $S_{z 4}$ & $\begin{array}{l}\text { Due to mechanical failure (steering or motion loss), tanker deviates from course, strikes } \\
\text { other ship or object and suffers hull damage. }\end{array}$ & $\mathrm{x}$ & $\mathrm{x}$ & $\mathrm{x}$ & $\mathrm{x}$ & & \\
\hline & $S_{z 5}$ & $\begin{array}{l}\text { Due to no observance of collision prevention regulations, tanker strikes other ship or ob- } \\
\text { ject and suffers hull damage. }\end{array}$ & $\mathrm{x}$ & $\mathrm{x}$ & & & & \\
\hline & $S_{z 6}$ & $\begin{array}{l}\text { During mooring operations, due to misconduct of the crew or shore personnel, tanker } \\
\text { strikes other ship, quay or other object and suffers hull damage }\end{array}$ & $\mathrm{x}$ & $\mathrm{x}$ & & & & \\
\hline$K_{3}$ & $S_{z 7}$ & Tanker suffers fire or explosion & $\mathrm{x}$ & $\mathrm{x}$ & $\mathrm{x}$ & $\mathrm{x}$ & & $\mathrm{x}$ \\
\hline$K_{4}$ & $S_{z 8}$ & Tanker suffers hull structural failure & $\mathrm{x}$ & $\mathrm{x}$ & $\mathrm{x}$ & $\mathrm{x}$ & & $\mathrm{x}$ \\
\hline
\end{tabular}

maritime safety and pollution prevention from tankers requirements, introduced by IMO in the last decade, in particular gradual elimination of single hull tankers from the world market had positive impact on the reduction of oil outflow event probability rate.

\section{Conclusions}

1. Estimation of oil outflow event probability, as well as evaluation of factors having influence on it, is relevant, firstly, to assessment of risk, posed by tankers operating in particular navigational area, secondly, to selection of measures, related to mitigation of hazards posed by tankers to the marine environment, and lastly, to risk-based dislocation of oil pollution combating means. In navigational areas with one or several oil terminals, where tanker traffic is not intensive, and accidents with oil pollution are rare, model for probabilistic assessment of oil outflow event, caused by tanker accident can be used.

2. Estimation of probabilistic parameters for the Lithuanian responsibility sea area, using proposed model revealed, that the highest rate of grounding/stranding probability is in the Klaipeda Port area, which two times exceeds collision probability. However, it is more than two times credible, that oil outflow event in Klaipeda Port area will occur due to collision, rather than due to grounding/stranding. It was assessed in the research, that probability of at least one tanker accident per year, followed by oil outflow is equal to 0,01147 .

3. Model, proposed in the paper can also be applied in navigational areas, where oil transportation conditions for tankers differ substantially from those, which are in LRSA. In that case methods, used for estimation of parameters, necessary for application of oil outflow probability evaluation model should be revised.

\section{References}

1. US National Oceanic and Atmospheric Administration. Oil spill case histories, 1967-1991, NOAA, Washington, 1992

2. SMAILYS, V.; ČESNAUSKIS, M. Estimation of expected cargo oil outflow from tanker involved in casualty. Transport, 2006, Vol XXIV, No 4, p. 293-300.

3. BAUBLYS, A. Assessment of statistical probability of the technological transportation process. Transport, 2002, Vol XVII, No 4, p. 127-136.

4. BAUBLYS, A. Probability models for assessing transport terminal operation. Transport, 2007, Vol XXII, No 1, p. 3-8.

5. ČESNAUSKIS, M.; TARASEVIČIUS, R. Analysis of statistics and investigations of marine casualties, registered in Lithuanian competent authorities during the period of 1999-2003 m. Sea \& Environment, 2004, Vol 2, Klaipeda, p. 33-40 (in Lithuanian).

6. PAPANIKOLAOU, A.; ElIOPOULOU, E.; MIKE LIS, N. et al. Casualty analysis of tankers. In RINA Conference „Learning from Marine Accidents III“, London, 2006.

7. International Collaborative FSA study-screening of generic hazards, Submision of United Kingdom to the International Maritime Organization, (MSC 74/INF.4), London, 2001.

8. SMAILYS, V.; LEBEDEVAS, S.; SENČILA, V. Marine environment protection program for transportation of orimulsion and oil products (Jūros vandens apsaugos programa transportuojant orimulsiją ir naftos produktus). Klaipėda: Klaipėda University, 1997 (in Lithuanian).

9. SMAILYS, V.; DAUKŠAS, K.; BEREIŠIENĖ, K. Orimulsion transportation safety assessment in the seaport of Klaipeda. Environmental Research, Engineering and Management, 2005, No 1(31), p. 14-20.

10. Maritime safety authority of New Zeland. Guidelines for port and harbour risk assessment and safety management systems in New Zeland. Public Consultation draft, 2004.

11. DELAUTRE, S.; AKSU, S.; TUZCU, C. et al. Hazard identification and risk ranking of aframax tankers by ex- 
pert judgment. International Maritime Association of the Mediterranian, IMAM Lisbon, Portugal, 2005.

12. International Maritime Organisation. Guidelines for formal safety assessment (FSA) for use in the IMO rulemaking process, MSC/Circ.1023, MEPC/Circ.392, London, IMO 2002

13. KNAPP, S.; HANS FRANSES, Ph. The overall view of the effect of inspections and evaluation of the target factor to target substandard vessels. Econometric Institute, Erasmus University Rotterdam, Report 2006-31.

14. PAULAUSKAS, V. Navigational risk assessment of ships. Transport, 2006, Vol XXI, No 1, p. 12-18.

15. Det Norske Veritas, Safety of shipping in coastal waters (SAFECO). Final report, 1999.

16. Revised interim guidelines for the approval of alternative methods of design and construction of oil tankers under regulation $13 \mathrm{f}$ (5) of Annex I of MARPOL 73/78, resolution MEPC. 110 (49), International Maritime Organisation, 2003.

17. Comparative study of double-hull and single-hull tankers, Herbert Engineering Corporation, San Fransisco, California, 1996.

18. ROSQVIST, T. On the use of expert judgment in the qualification of risk assessment. Espoo 2003. Technical Research Centre of Finland, VYY Publications 507. 48 p.

19. PAPANIKOLAOU, A.; ELIOPOULOU, E.; MIKELIS, N. Impact of hull design on tanker pollution. In 9th International Marine Design Conference-IMDC06, Ann Arbor-Michigan, 16-19 May, 2006.

20. DAVID, H. A. The method of paired comparison. Griffin and Co, London, 1969.

21. KENDALL, M. Rank correlation methods. Griffin and Co, London, 1970. 